\title{
STUDY CONCERNING CHARACTERIZATION OF SOME RECYCLED CONCRETE AGGREGATES
}

\begin{abstract}
Ion ROBU - Professor, PhD, Technical University of Civil Engineering, Faculty of Railways, Roads and Bridges,
\end{abstract} e-mail: irobu2004@yahoo.fr

Claudiu MAZILU - Lecturer, PhD, Technical University of Civil Engineering, Faculty of Railways, Roads and Bridges, e-mail: claudiumazilu@yahoo.com

Radu DEJU - $1^{\text {st }}$ degree TD engineer, PhD, Horia Hulubei National Institute for R\&D in Physics and Nuclear Engineering, e-mail: dejuradu@yahoo.com

\begin{abstract}
Using recycled concrete aggregates (RCA) is a matter of high priority in the construction industry worldwide. In countries like the Netherlands, Denmark, Germany, USA, Japan, France recycled concrete aggregates obtained from demolition are valorized up to $90 \%$, mainly for road construction and less in the manufacture of new concrete.

Recycled concrete aggregates (RCA) generally result from a two-stage crushing of the concrete obtained from demolition followed by the screening and removal of contaminants (wood, plastic, metal, ceramics etc.). The literature review showed that the recycled aggregates concrete (RAC) are less resistant, with 15 to $40 \%$ versus concrete obtained using natural aggregates. The factors that play a role in the reducing of mechanical resistance are presented and analyzed in this study.

This paper presents a study on the use of recycled aggregates, from a concrete of specified class, to acquire new cement concrete with different percentages of recycled aggregates. In order to evaluate the influence upon the properties of the new concrete obtained, recycled aggregates have been characterized in terms of the granulosity, the granule shape, the absorption of water, behavior to the Los Angeles test, the content of attached mortar etc.
\end{abstract}

Keywords: recycled aggregate, properties, concrete

\section{Introduction}

Natural aggregates (gravel and crushed) are essential non-renewable resources which are used for infrastructure works and civil engineering. In European Union member states from Southeast Europe, it is estimated that the construction industry will grow by $4.2 \%$ thereafter complicating aggregate supply management [1]. In addition, a significant additional problem that can be associated to the aggregates industry is wasting potential resources through waste dumping of inert waste, especially waste from construction and demolition activities.

In highly developed countries this inert waste is processed in recycling plants, fixed or mobile, to obtain recycled aggregates that are used according to specific rules as a complementary resource for the supply aggregates [2-4]. In 2012 in Romania, less than 10\% of construction and demolition waste (including concrete) are valorized, while the European Union requires that by 2020 this proportion should be at least 70\% (Directive 2008/98 / EC on waste, transposed into Romanian legislation by Law 211/2011) [5].

In the composition of the waste from construction and demolition prevails $\left(\% \mathrm{~m}^{3}\right.$ waste $/ 100 \mathrm{~m}^{3}$ total waste): $42 \%$ Concrete (original aggregate + mortar adherent), $26 \%$ masonry materials (brick), 20\% bitumen, 6\% rubble, 6\% wood, metal, plastic, [6]. The main phases that characterize a manufacturing process of the waste from construction and demolition, are: crushing, screening and separation. Depending on the efficiency of waste processing and the quality of recycled aggregate concrete (RCA) obtained, poor quality aggregates can be used as foundation material for roads while high quality ones for new concrete in construction. 
In the next period a fast growing of the amount of recycled aggregate concrete is expected following the end of the life cycle of buildings constructed in the 1960s, 1970, which led to the development of new technologies for the production of recycled aggregates to high quality which can be used to obtain new concrete [7-8].

To obtain good quality concrete using recycled aggregate is necessary to meet the minimum requirements defined by the rules for the manufacture of concrete with natural aggregate. Properties of recycled aggregate are the basis for concrete quality; also establishing appropriate proportions between components and the concrete production methods are extremely important for its quality [9-11].

Recycled aggregates are composed of the original aggregates and adherent mortar. The relative proportions of these components varies with the type of the original concrete, properties of the natural aggregate, cohesion between natural aggregate and mortar, and the type of crusher used in production. The size of particles has also an important role. The bigger particles tend to contain a higher amount of natural aggregate and the small ones are generally formed preponderantly of crushed mortar. Adhered mortar is a porous material whose porosity depends on the $\mathrm{A} / \mathrm{C}$ ratio of recycled concrete used. Usually, there are $30-60 \%$ ( $\%$ vol.) adhered mortar to the surface of the RCA, rate dependent on the size, nature and the initial roughness of the aggregate used in the originally concrete, [9].

The crushing of materials from demolition is carried out with jaw crushers or hammer crushers. Jaw crusher enable processing voluminous blocks according to their input. They have the inconvenience of a coarse fragmentation which requires most often a secondary crushing. Hammer crusher has the following advantages: enable better fragmentation from the first crushing and a good separating of the reinforcement from concrete. Inconvenience is the fact that the dimensions of workpiece materials are limited because of the operating principle of these crushers and their accentuated wear (three times higher than in jaw crushers) [12].

With the necessary adjustments, concrete crushers can be configured to produce almost any required particle size, although there is generally an excess of fine part produced. For the same amount of fine material produced, $60 \%$ of the granules obtained with crusher hammer are less than $10 \mathrm{~mm}$ compared to only $40 \%$ of those obtained with jaw crushers. The aggregates obtained with impact crusher are more cubic, $[13,14]$.

Recycled concrete aggregates tend to be rougher and more angular compared to natural aggregates and their properties (physical, mechanical, chemical) different because of the production process (crushing) and the presence of mortar on their surface.

Compositionally, recycled concrete aggregates have less of a $\mathrm{SiO}_{2}$ content than natural gravel and a higher $\mathrm{CaO}$ content while as mineralogical components contain silica, calcium carbonate and feldspath, [15].

The water absorption capacity of RCA is higher than with conventional aggregates. The main factor that influences the absorption of RCA is the presence of attached mortar which is porous and highly absorbent, with a surface area greater than that of natural aggregates.

The RCA bulk density decreases with the increase of attached mortar content due to lower density of the mortar in relation to the natural aggregate. The decrease is also observed when the size of the particles increases as, in general, the mortar content increases.

Mass loss from Los Angeles test abrasion has, usually, higher values for RCA than for natural aggregates due to the brittleness of mortar and presence of the natural aggregate particles that were only fractured after crushing. According to the specifications for aggregates used in concrete, aggregates can be used to make concrete if Los Angeles weight loss does not exceed $50 \%[16,17]$. 
The durability of recycled concrete aggregates is affected by freeze-thaw cycles. Concrete pavers that had suffered from freeze-thaw as a result of using a coarse aggregate sensitive to frost, are recycled as sub-base for roads, [18].

The potential of alkali-silica reactions in new concrete containing RCA is influenced by the initial level of the alkali in old concrete, by the remaining reaction potential of recycled aggregates and by the alkali content of new concrete. The use of low-lime Class F fly ash and slag cement has greatly reduced ASR expansion in new concrete. Other mitigating techniques include limiting the content of RCA fines, reducing concrete permeability through a lower water content, using admixtures such as lithium nitrate, and reducing time exposure to moisture. Research and construction projects have demonstrated that, with appropriate selection of cementitious materials, RCA containing reactive (and even highly reactive) aggregate can be used safely. [18].

The presence of impurities in RCA determine major reductions in compressive strength of recycled aggregate concrete (RAC), [19]. In the recycled concrete aggregates from sources exposed a long time to thaw chemicals, high levels of chlorides were found that often raises issues regarding concrete durability and, in time, corrosion of embedded reinforcing steel. German rules specify the conditions of purity concerning RCA: maximum carbon content $0.5 \%$ for $0 / 4 \mathrm{~mm}$ sort and $0.1 \%$ for $4 / 8 \mathrm{~mm}$; sulphide and sulfur content, maximum $1 \%$; chloride content, maximum $0.02 \%$, [19,20].

RCA must also meet the environmental conditions. Thus, the proposed limit values (maximum) by German standards for toxic elements are: As $-50 \mu \mathrm{g} / 1, \mathrm{~Pb}-100 \mu \mathrm{g} / \mathrm{l}, \mathrm{Cd}-5 \mu \mathrm{g} / \mathrm{l}, \mathrm{Cr}-100$ $\mu \mathrm{g} / \mathrm{l}, \mathrm{Cu}-200 \mu \mathrm{g} / \mathrm{l}, \mathrm{Ni}-100 \mu \mathrm{g} / \mathrm{l}, \mathrm{I}-2 \mu \mathrm{g} / \mathrm{l}, \mathrm{Zn}-400 \mu \mathrm{g} / \mathrm{l},[17,21]$.

A problem facing the recycled concrete aggregates is the potential for precipitation. Crushing concrete reveals previously unexposed surfaces that usually contain some calcium hydroxide, as well as some unhydrated or partially hydrated cement grains. Calcium hydroxide is highly soluble and is easily leached from the RCA particles from stockpiles and drainable subbase layers, resulting in highly alkaline runoff and effuent. The dissolved calcium hydroxide can combine with $\mathrm{CO}_{2}$ to form $\mathrm{CaCO}_{3}$, which precipitates out of solution to form a heavy, creamy substance. Dust and other fine particles resulted from the crushing, screening and handling operations can also settle on filter fabrics and in drain pipes, further exacerbating the problem. Over time, these materials can clog drain pipes and blind filter fabrics, [21].

After crushing to obtain RCA, small amounts of particulates (dust crusher) remain on RCA which lead to increasing demand for water and reduced mortar - aggregate adherence in new concrete. Washing aggregates, which is often performed for natural aggregates, is not necessary in this case but can be helpful or desirable in some cases [22].

In the literature [23-25], it was shown that the recycled aggregate concrete (RAC) are less resistant, with 15 to $40 \%$ versus concrete with natural aggregates. The factors influencing reducing mechanical resistance include:

- mechanical strength of the original concrete and respectively for recycled aggregates obtained;

- the origin of the original concrete from multiple sources versus once source;

- the amount of attached mortar to recycled aggregates;

- the percentage of replacing natural aggregates with recycled aggregates;

- use of fine recycled aggregates;

The present study aimed the characterization of some recycled concrete aggregate obtained from established class concrete and their use in different proportions to achieve new concrete. The new concretes are also characterized (density, mechanical strength, modulus of elasticity etc.) and the factors affecting their properties analyzed. 


\section{Recycled concrete aggregates}

In the project PN II 145/2012, were made several batches of concrete class C16 / 20, C25 / 30 and C35 / 45. The compositions calculation was made according NE012 / 2007 CP012 / 2007 so that all reference concrete fulfill the following conditions:

a. slump class $\mathrm{S}_{2}(50 \div 90 \mathrm{~mm})$;

b. compression strengths of the samples corresponding to concrete class;

c. river aggregate $0 / 16 \mathrm{~mm}$ on three sorts particle size: $0 / 4 ; 4 / 8$ and $8 / 16 \mathrm{~mm}$;

d. additive superplasticizer / high range water reducer.

CEM V A (S-V) 42,5N cement was used and superplasticizer Glenium 27 as an additive in a proportion of $1 \%$ (by weight) relative to cement. Correction amount of water mixing was done with $-5 \%(+10 \%$ due to the $16 \mathrm{~mm}$ sieve sorts, $-15 \%$ because the additive superplasticizing $)$. The compositions for $1 \mathrm{~m}^{3}$ established classes concrete are shown in table 1 .

Table 1

The composition of reference concretes (for $1 \mathbf{~ m}^{3}$ concrete)

\begin{tabular}{|c|c|c|c|c|c|c|}
\hline $\begin{array}{l}\text { Concrete } \\
\text { class }\end{array}$ & $\begin{array}{l}\text { Aggregates, } \\
\text { weight } \%\end{array}$ & $\begin{array}{l}\text { Aggregate on } \\
\text { sorts for } \mathbf{1 m}^{3} \\
\text { concrete, } \mathbf{k g}\end{array}$ & $\begin{array}{l}\text { Cement, } \\
\text { kg }\end{array}$ & $\begin{array}{l}\text { Water, } \\
\text { liters }\end{array}$ & $\mathbf{A} / \mathbf{C}$ & $\begin{array}{l}\text { Additive } \\
\text { Glenium 27, } \\
\text { liters }\end{array}$ \\
\hline $\mathrm{C} 25 / 30$ & \multirow{3}{*}{$\begin{array}{l}\text { Passes: } \\
\mathrm{T}_{4}=45 \% \\
\mathrm{~T}_{8}=70 \% \\
\mathrm{~T}_{16}=100 \% \\
\text { Granulometric } \\
\text { composition: } \\
0-4=45 \% \\
4-8=25 \% \\
8-16=30 \%\end{array}$} & $\begin{array}{l}0 / 4-815,9 \\
4 / 8-453,3 \\
8 / 16-543,9\end{array}$ & 345,5 & 190 & 0,55 & 3,3 \\
\hline C35/45 & & $\begin{array}{l}0 / 4-762,0 \\
4 / 8-423,4 \\
8 / 16-508,0\end{array}$ & 475 & 190 & 0,40 & 4,5 \\
\hline $\mathrm{C} 16 / 20$ & & $\begin{array}{l}0 / 4-864,5 \\
4 / 8-480,3 \\
8 / 16-576,4\end{array}$ & 270,4 & 175,8 & 0,65 & 2,57 \\
\hline
\end{tabular}

Fresh concrete was characterized in terms of workability (determination of slump by Abrams cone), apparent density, air content, [26, 27]. All concrete samples, cubes $(\mathrm{d}=15 \mathrm{~cm})$ and cylinders $(\mathrm{dxh}=15 \times 30 \mathrm{~cm})$, were demoulding after a day and kept in water at $20^{\circ} \mathrm{C} \pm 2^{\circ} \mathrm{C}$, until the date of 28 days necessary for determinations on hardened concrete. Preparing and maintaining test specimens was done according to standards.

Compressive strength was determined following a request by friction using a hydraulic press $3000 \mathrm{kN}$ with a loading speed of $0.6 \pm 0.2 \mathrm{~N} / \mathrm{mm}^{2} \cdot \mathrm{s}$, according to SR EN $12390-3$. Previously, concrete samples (cubes) were weighed and geometrically measured to calculate the apparent density. Values of the properties of fresh and hardened concrete are listed in table 2. The achievement of strength class proposed in the research was verified by comparing the compressive strength at 28 days, with preliminary resistance for the class shown in the last column of table 2 .

Table 2

Properties of fresh and hardened concrete

\begin{tabular}{|c|c|c|c|c|c|c|c|}
\hline \multirow{3}{*}{$\begin{array}{l}\text { Concrete } \\
\text { class }\end{array}$} & \multicolumn{3}{|c|}{ Properties of fresh concrete } & \multicolumn{4}{|c|}{ Properties of hardened concrete } \\
\hline & \multirow[t]{2}{*}{$\begin{array}{l}\text { Slump, } \\
\text { mm }\end{array}$} & \multirow{2}{*}{$\begin{array}{l}\text { Apparent } \\
\text { density, } \\
\mathrm{Kg} / \mathrm{m}^{3}\end{array}$} & \multirow{2}{*}{$\begin{array}{c}\text { Air } \\
\text { content, } \\
\%\end{array}$} & \multirow{2}{*}{$\begin{array}{l}\text { Apparent } \\
\text { density, } \\
\mathrm{Kg}^{3} \mathbf{m}^{3}\end{array}$} & \multicolumn{2}{|c|}{$\begin{array}{c}\text { Compressive } \\
\text { strength, } f_{c}, \mathrm{MPa}\end{array}$} & \multirow{2}{*}{$\begin{array}{c}\begin{array}{c}\text { Preliminary } \\
\text { strength, MPa }\end{array} \\
28 \text { days }\end{array}$} \\
\hline & & & & & 7 days & 28 days & \\
\hline $\mathrm{C} 25 / 30$ & 55 & 2350 & 4,0 & 2382 & 39,6 & 46,3 & 42 \\
\hline $\mathrm{C} 35 / 45$ & 60 & 2360 & 1,5 & 2368 & 42,8 & 62,1 & 56,5 \\
\hline $\mathrm{C} 16 / 20$ & 50 & 2320 & 2,9 & 2358 & 21,9 & 34,8 & 29 \\
\hline
\end{tabular}




\subsection{Obtaining of the recycled concrete aggregate}

Tests for producing recycled aggregate was carried out using concrete samples of the established three classes after 28 days of storage under the above conditions. Cubes with $150 \mathrm{~mm}$ side were crushed in a first stage with a jaw crusher Liebherr type set at $50 \mathrm{~mm}$ nominally. The resulting material was separated by sieving on granulometric sorts and 10-50 sort was used for preliminary tests of crushing in the second stage with a jaw crusher BB 200 Retsch model, respectively a hammer crusher Buffalo Shuttle WA-12-H model.

The fine aggregate, sort $0-2$, was analyzed by granulometric point of view getting elementary sorts $0-0.063 ; 0.063-0.125 ; 0.125-0.25 ; 0.25-0.5 ; 0.5-1 ; 1-2 ;>2$ for all three concrete classes for the two crushing variants in the second stage. Comparing granulometric compositions for recycled aggregates (Table 3) obtained with an impact crushing to those obtained with a jaw crusher, generally, a higher proportion of coarse parts(sorts $1-2 ;>2)$ in the aggregate obtained with a jaw crusher is observed, particularly for concrete aggregates from larger class. This is in accord with the literature data according to which the hammer crusher produce more fine part than the jaw crusher and recycled aggregate derived from a higher class concrete is coarser than that coming from a lower concrete.

Table 3

Granulometric composition for recycled aggregates produced by crushing in second stage

\begin{tabular}{|c|c|c|c|c|c|c|}
\hline \multirow{2}{*}{ Sort } & \multicolumn{6}{|c|}{ Granulometric composition, by weight \% } \\
\cline { 2 - 7 } & \multicolumn{3}{|c|}{ Hammer crusher } & \multicolumn{3}{c|}{ Jaw crusher } \\
\cline { 2 - 7 } & $\mathbf{C 1 6 / 2 0}$ & $\mathbf{C 2 5 / 3 0}$ & $\mathbf{C 3 5 / 4 5}$ & $\mathbf{C 1 6 / 2 0}$ & $\mathbf{C 2 5 / 3 0}$ & $\mathbf{C 3 5 / 4 5}$ \\
\hline$>\mathbf{2 , 0}$ & 8 & 7 & 10 & 4 & 19 & 14 \\
\hline $\mathbf{1 - 2}$ & 11 & 10 & 12 & 16 & 13 & 16 \\
\hline $\mathbf{0 , 5 - 1}$ & 26 & 29 & 27 & 32 & 29 & 31 \\
\hline $\mathbf{0 , 2 5 - 0 , 5}$ & 21 & 23 & 21 & 20 & 16 & 20 \\
\hline $\mathbf{0 , 1 2 5 - 0 , 2 5}$ & 19 & 24 & 14 & 14 & 11 & 11 \\
\hline $\mathbf{0 , 0 6 3 - 0 , 1 2 5}$ & 11 & 6 & 12 & 11 & 11 & 7 \\
\hline $\mathbf{0}-\mathbf{0 , 0 6 3}$ & 4 & 1 & 4 & 3 & 1 & 1 \\
\hline
\end{tabular}

Finally, for the production of recycled aggregate concrete and to compare their properties with those of the original concrete, through the successive crushing and screening, there were obtained three granulometric classes of recycled aggregate $0-4 ; 4-8$ and 8-16. In this study, for new concrete, only recycled aggregate derived from C25/30 concrete class was used. Images of these aggregates, the coarse sorts 4-8 and 8-16 are shown in fig.1-2.
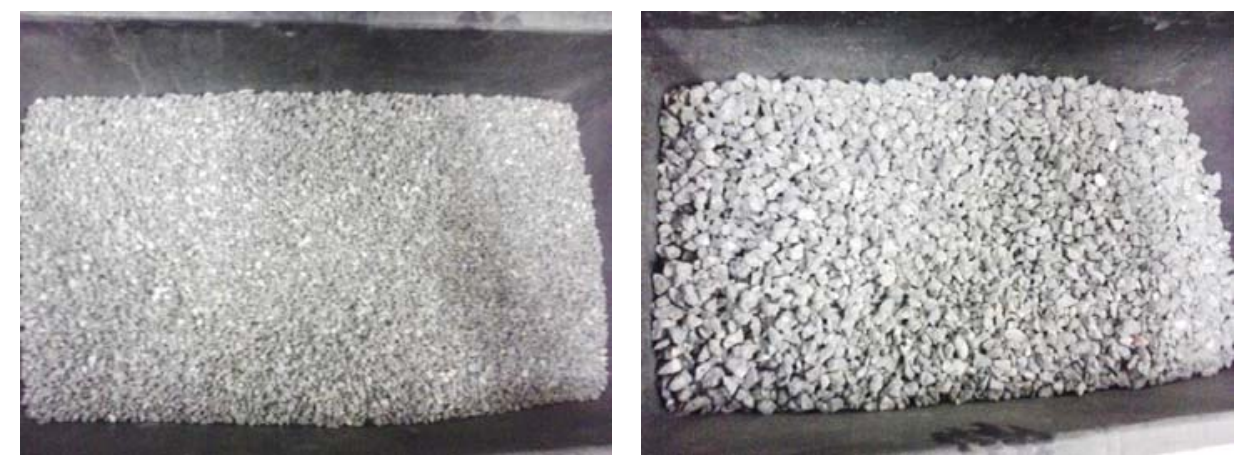

Fig. 1-2 The recycled aggregates, sorts 4-8 and 8-16

\subsection{Characterization of recycled concrete aggregate}

Recycled aggregates, as well as natural aggregates, do not all have the same features, so that, depending on their specific performances, they are more or less suitable for certain applications. Therefore, it's of great importance to know the properties (density, granulosity, granule shape, 
water absorption, weight loss to Los Angeles test, attached mortar content etc.) and the behavior of aggregates towards different factors (mechanical strength, exposure to freeze-thaw cycles or to water etc.) rather than knowing their origin.

\section{Density}

For calculating the composition of recycled aggregate concrete the bulk density of the aggregate must be known. In determining density (volumic mass) the displacement method and toluene as inert liquid were used to not falsify the volume due to the reaction of non-hydrated cement from old attached mortar and water. The results, shown in comparison with those obtained on natural aggregate, are presented in table 4 .

Density for recycled aggregate from crushed concrete

\begin{tabular}{|l|c|c|c|}
\hline \multirow{2}{*}{\multicolumn{1}{|c|}{ Aggregate }} & \multicolumn{3}{|c|}{ Density, $\mathbf{~ K g / \mathbf { d m } ^ { 3 }}$} \\
\cline { 2 - 4 } & sort 0-4 & sort 4-8 & sort 8-16 \\
\hline River aggregate & 2,620 & 2,630 & 2,630 \\
\hline Recycled concrete aggregate & 2,340 & 2,290 & 2,240 \\
\hline
\end{tabular}

The experimental values confirms that due to the porous attached mortar the density of the recycled aggregate is less than the density of original aggregate. Also, the density decreased with the increasing size of the grain aggregate.

\section{Granulometric distribution}

Recycled concrete aggregate derived by class C25/30, 10-50 sort, was divided into elementary sorts $10-16,16-31.5,31.5-45$ and $45-50$. Table 5 shows the particle size distribution obtained in a volume of $200 \mathrm{~kg}$. Results on different samples are comparable.

Table 5

Granulometric distribution for recycled concrete C25/30 aggregate

\begin{tabular}{|c|c|c|c|c|}
\hline \multirow{2}{*}{$\begin{array}{c}\% \\
\text { weight }\end{array}$} & \multicolumn{4}{|c|}{ Granulometric distribution } \\
\cline { 2 - 5 } & $10-16$ & $16-31,5$ & $31,5-45$ & $45-50$ \\
\cline { 2 - 5 } & 15 & 35 & 36 & 14 \\
\hline
\end{tabular}

\section{Granule shape}

Under the current rules, the granule shape is assessed by shape index and flatness coefficient; they were determined for recycled coarse aggregate, 16-31.5 sort. The values are presented in table 6 along with similar data obtained for natural river aggregate and crushed aggregate, 12.516 sort. As expected, both the shape index, SI, and the flatness coefficient, A, has high values which shows a high percentage of non-isometric granules, recycled aggregates classification being made into unfavorable categories. All features in terms of the granule shape, for recycled aggregate, are inferior to the characteristics determined for natural aggregates.

Characteristics of granule shape

\begin{tabular}{|l|c|c|}
\hline Type of aggregate & $\begin{array}{c}\text { Shape index, \% } \\
\text { /Category }\end{array}$ & $\begin{array}{c}\text { Flatness coefficient, \% } \\
\text { / Category }\end{array}$ \\
\hline River aggregate, $12,5-16$ sort & $2,5 / \mathrm{SI}_{15}$ & $5,3 / \mathrm{FI}_{15}$ \\
\hline Crushed aggregate, $12,5-16$ sort & $13,0 / \mathrm{SI}_{15}$ & $18,2 / \mathrm{FI}_{20}$ \\
\hline Recycled aggregate, $16-31,5$ sort & $30,5 / \mathrm{SI}_{40}$ & $33,5 / \mathrm{FI}_{50}$ \\
\hline
\end{tabular}


Water absorption coefficient was determined for recycled coarse aggregate 10-16, 16-31.5, 31.5-50 sorts. The determination was done after 2 hours, respectively 24 hours, while the recycled aggregate samples were stored in water at $22^{\circ} \mathrm{C}$. The values are presented in table 7 compared to the results for the river and for the crushed aggregate, 4-8 and 8-16 sorts.

Table 7

The coefficient of water absorption, for natural and recycled coarse aggregate

\begin{tabular}{|l|l|c|c|c|}
\hline \multirow{2}{*}{ Aggregate } & \multicolumn{3}{c|}{ The coefficient of water absorption, in \%, for } \\
\cline { 3 - 5 } \multirow{2}{*}{ Recycled aggregate } & $\mathbf{1 0 - 1 6}$ sort & $\mathbf{1 6 - 3 2}$ sort & 32-50 sort \\
\cline { 2 - 5 } & $\mathbf{2 4}$ hours in water & 5,59 & 5,10 & 4,64 \\
\hline \multirow{3}{*}{\begin{tabular}{l} 
Natural aggregate \\
\cline { 2 - 4 }
\end{tabular}} & river & 5,74 & 5,32 & 5,12 \\
\cline { 2 - 5 } & crushed & $\mathbf{4 - 8}$ sort & $\mathbf{8 - 1 6}$ sort & \\
\cline { 2 - 4 } & 1,40 & 0,95 & \\
\hline
\end{tabular}

The results show that the water absorption of recycled aggregates is much higher than the original aggregates (natural), this being due to the presence of old mortar, porous, attached to the gravel granules. Also, there is a slight decrease in the coefficient of water absorption with the growth of granule aggregate size which suggests that the attached mortar is in a higher proportion on the smaller granules.

\section{Behavior to the Los Angeles test}

The weight loss following the Los Angeles test was determined, according to SR EN 1097-2: 2010, for recycled aggregate, 10-16 sort, achieved with an impact crusher. The Los Angeles test was performed on a Matest machine A075 type, using nine steel balls and a 31rpm rotational speed of the drum machine. To compare results, Los Angeles coefficient was determined for river aggregate and crushed aggregate, using 8-16 sort. Los Angeles coefficient value for recycled aggregates was significantly higher than values obtained for natural aggregate (tab.8).

Table 8

Los Angeles coefficient for recycled aggregate, natural aggregate respectively

\begin{tabular}{|l|c|}
\hline \multicolumn{1}{|c|}{ Type of analyzed aggregate } & Los Angeles coefficient, $\%$ \\
\hline Recycled aggregate, 10-16 sort & 43,5 \\
\hline River aggregate, 8-16 sort & 32,0 \\
\hline Crushed aggregate, 8-16 sort & 30,7 \\
\hline
\end{tabular}

This behavior is justified by the presence of hardened mortar attached to original aggregates, which during the Los Angeles test detach as a fine powder. The result is in correlation with data from the literature and allows the utilization of the recycled aggregate in new concrete.

\section{The content of attached mortar in the recycled aggregate}

Juan Sanchez et all. [28] has found the mortar content variation of RCA to fit the aggregates size:

- $\quad$ RCA 4-8 mm sort contains 33-55\% mortar;

- RCA 8-16 mm sort contains 23-44\% mortar.

Therefore, for this study the proportion of attached mortar from recycled aggregate is important and how it varies depending on the granulometric sort and on theconcrete class it comes from. The literature lists several methods of determining the proportion of attached mortar [28], in this study the method of heat treatment was chosen. This method consists in heat treating of the 
recycled aggregate, followed by thermal shock and the separation of the mortar from the surface of the original aggregate granules. Recycled aggregate from three classes of concrete C16/20, $\mathrm{C} 25 / 30$ and $\mathrm{C} 35 / 45$ were used for two granulometric sorts: $4-8$, respectively 8-16.

The content of attached mortar, in \% weight, is calculated with the equation 1 :

$$
\% \text { attached mortar }=\left[\left(m_{i}-m_{f}\right) / m_{i}\right] \cdot 100
$$

where: $m_{i}$ - mass of the recycled aggregate sample; $m_{f}$ - mass of the aggregate sample after the mortar has been removed; the sample was sieved on $4 \mathrm{~mm}$ sieve.

The data presented in fig. 3 stands out the aggregate size as one of the factors that affects the mortar content. The proportion of attached cement is, in general, higher in the lower fraction (48) than in the upper (8-16), for the same class of the original concrete. 4-8 sort has a content of $35-54 \%$ attached mortar while $8-16$ sort between 35-42\%. Also, for both granulometric sorts studied, the percentage of the attached mortar increases as the original concrete class of provenance of recycled aggregate is greater. The results are in agreement with literature data.

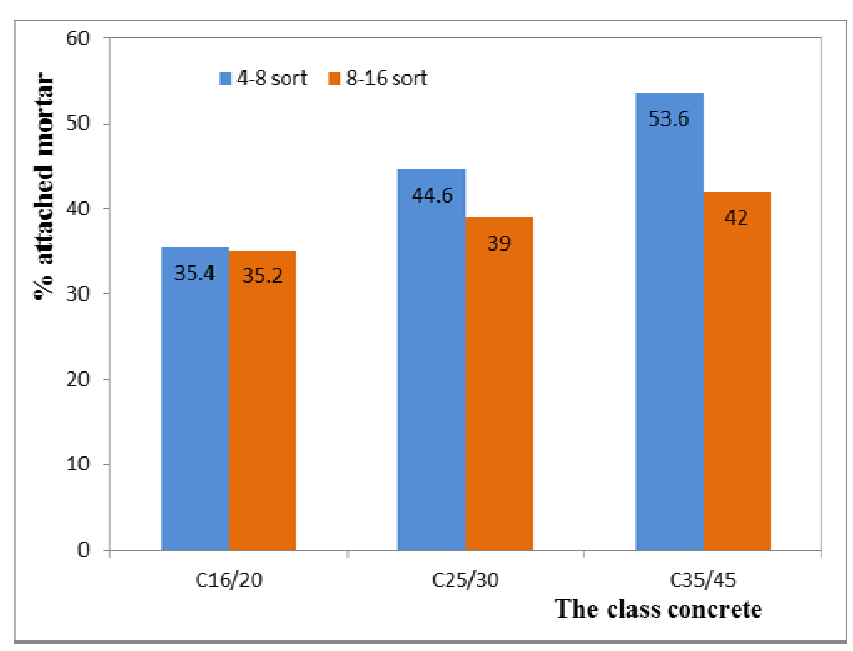

Fig. 3 - Variation of the attached mortar percentage depending on the concrete class of provenance of the recycled aggregate, for 4-8 sort and 8-16 sort respectively.

\section{Recycled Aggregate Concrete}

Using recycled aggregates made from concrete of C25/30 class, new concretes were made, based on the same recipe and with similar target characteristics, to track changes of their properties to a substitution degree of natural aggregate between 0 and $100 \%$.

Due to the porosity of recycled concrete aggregate, given by the attached mortar to the original aggregate granule, the water absorbed by the aggregate must be taken into account when determining the composition of recycled aggregate concrete. Thus, it requires the establishment of two $\mathrm{A} / \mathrm{C}$ ratios; a global $\mathrm{A} / \mathrm{C}$ ratio which includes water absorbed by the aggregate and effective $\mathrm{A} / \mathrm{C}$ ratio referring only to the water present in the mixture in relation to the binder.

\subsection{Obtaining the recycled aggregate concrete}

The amounts of mixing water, cement, aggregates and additives were established according to NE012/2007 and CP012/2007, following the same steps as in the case of a natural aggregate concrete.

The proportions in the mixture were calculated so as to satisfy the following conditions:

- the recycled aggregate to replace the natural aggregate in a proportion of $0 \%$ (reference), $20 \%, 40 \%, 60 \%, 80 \%$ and $100 \%$, for all sorts used; 
- the recycled aggregate was used dry, the necessary water for saturation of the recycled aggregate was added during the components' mixing;

- river aggregate and recycled from crushed concrete, $0 / 16 \mathrm{~mm}$ on 3 granulometric sorts: $0 / 4 ; 4 / 8$ and $8 / 16 \mathrm{~mm}$, respectively;

- $\quad$ slump class of the fresh concrete $\mathrm{S}_{2}(50 \div 90 \mathrm{~mm})$;

- superplasticizer additive / high range water reducer.

As with concrete from which the recycled aggregate was obtained, CEM V A S-V 42,5 N cement was used and as an additive: superplasticizer Glenium 27 (1\% weight of cement). Obtaining, preserving and preparation of samples for testing was done according to the rules adopted for concrete with natural aggregate.

In table 9 are shown the compositions for $1 \mathrm{~m}^{3}$ concrete with different proportions of recycled aggregate (R1-R6) and some data of interest such as: fresh concrete slump, A/C global ratio, density of fresh concrete, experimental observations.

Table 9

Recycled aggregate concrete compositions

\begin{tabular}{|c|c|c|c|c|c|c|c|}
\hline \multirow[t]{2}{*}{$\begin{array}{c}\text { Code } \\
\text { samples }\end{array}$} & \multirow{2}{*}{$\begin{array}{l}\text { Cement, Water, } \\
\text { Effective A/C } \\
\text { ratio, Glenium } \\
27 \text { Additive }\end{array}$} & $\begin{array}{l}\text { Natural } \\
\text { aggregates } \\
\text { on sorts, } \\
\end{array}$ & $\begin{array}{l}\text { Recycled } \\
\text { aggregates } \\
\text { on sorts, } \\
\end{array}$ & \multirow{2}{*}{$\begin{array}{l}\text { fresh } \\
\text { concrete } \\
\text { slump, } \\
\text { mm }\end{array}$} & \multirow[t]{2}{*}{$\begin{array}{l}\mathrm{A} / \mathrm{C} \\
\text { global } \\
\text { (real) }\end{array}$} & \multirow{2}{*}{$\begin{array}{c}\text { Density } \\
\text { of fresh } \\
\text { concrete, } \\
\mathbf{k g} / \mathrm{m}^{3}\end{array}$} & \multirow[t]{2}{*}{ Observations } \\
\hline & & \multicolumn{2}{|c|}{ for $1 \mathrm{~m}^{3}$ concrete, $\mathrm{kg}$} & & & & \\
\hline $\begin{array}{c}\mathrm{R} 1 \\
0 \% \text { recycled }\end{array}$ & \multirow{6}{*}{$\begin{array}{l}\text { Cement: } 345 \mathrm{~kg} \\
\text { for } 1 \mathrm{~m}^{3} \text { concrete; } \\
\text { Water: } 190 \text { liters } \\
\text { for } 1 \mathrm{~m}^{3} \text { concrete; } \\
\text { Glenium } 27 \\
\text { Additive: } 3,3 \text { liters } \\
\text { for } 1 \mathrm{~m}^{3} \text { concrete; } \\
\mathrm{A} / \mathrm{C}=0,55\end{array}$} & $\begin{array}{l}0 / 4-815 \\
4 / 8-454 \\
8 / 16-545\end{array}$ & - & 65 & 0,47 & 2380 & Workable \\
\hline $\begin{array}{c}\text { R2 } \\
20 \% \text { recycled }\end{array}$ & & $\begin{array}{lr}0 / 4- & 650 \\
4 / 8- & 365 \\
8 / 16- & 435\end{array}$ & $\begin{array}{l}0 / 4-\quad 140 \\
4 / 8-75 \\
8 / 16-\quad 95\end{array}$ & 80 & 0,51 & 2350 & Workable \\
\hline $\begin{array}{c}\mathrm{R} 3 \\
40 \% \text { recycled }\end{array}$ & & $\begin{array}{ll}0 / 4- & 490 \\
4 / 8- & 275 \\
8 / 16- & 325 \\
\end{array}$ & $\begin{array}{ll}0 / 4- & 280 \\
4 / 8- & 155 \\
8 / 16- & 185 \\
\end{array}$ & 70 & 0,54 & 2340 & Workable \\
\hline $\begin{array}{c}\mathrm{R} 4 \\
60 \% \text { recycled }\end{array}$ & & $\begin{array}{l}0 / 4-325 \\
4 / 8-180 \\
8 / 16-220\end{array}$ & $\begin{array}{ll}0 / 4- & 415 \\
4 / 8- & 230 \\
8 / 16- & 280 \\
\end{array}$ & 90 & 0,57 & 2290 & $\begin{array}{l}\text { Slight water } \\
\text { separation }\end{array}$ \\
\hline $\begin{array}{c}\text { R5 } \\
80 \% \text { recycled }\end{array}$ & & $\begin{array}{lr}0 / 4- & 165 \\
4 / 8- & 90 \\
8 / 16 & -110 \\
\end{array}$ & $\begin{array}{ll}0 / 4- & 555 \\
4 / 8- & 310 \\
8 / 16- & 370 \\
\end{array}$ & 60 & 0,58 & 2270 & $\begin{array}{l}\text { Low cohesion, } \\
\text { Nonworkable }\end{array}$ \\
\hline $\begin{array}{c}\text { R6 } \\
100 \% \text { recycled }\end{array}$ & & - & $\begin{array}{l}0 / 4-695 \\
4 / 8-385 \\
8 / 16-465\end{array}$ & 50 & 0,62 & 2240 & $\begin{array}{l}\text { Low } \\
\text { cohesion, } \\
\text { Nonworkable }\end{array}$ \\
\hline
\end{tabular}

According to experimental observations, recycled aggregate concrete loses its cohesion and becomes more nonworkable as the percentage of recycled aggregate increases. If to the establishment of theoretical composition the $\mathrm{A} / \mathrm{C}$ ratio was 0.55 , the real (experimental), for carrying out the slump class the $\mathrm{A} / \mathrm{C}$ ratio was initially used small, in the case of compositions with 0,20 and 40\% recycled aggregate and over the theoretical value in the case of recipes with a lot of recycled aggregate ( 80 and $100 \%)$. This is due, of course,to the increase of need for absorption water when increasing the amount of recycled aggregates.

\subsection{Characterization of recycled aggregate concrete}

The recycled aggregate concrete obtained were characterized from the point of view of the properties of interest. This paper only refers to variation in apparent density and compressive strength of concrete with recycled aggregate content, following that in another study to be 
presented in detail all the properties analyzed. The tests were performed on cube sample with sides of $15 \mathrm{~cm}$, respecting current rules used for concrete with natural aggregate.

In the table 10 the values of apparent density for hardened concrete are shown, with different proportions of recycled aggregate, and the compressive strength of the same concrete. A decline in concrete density was observed with the increase in content of the recycled aggregate, situation also evidenced in the case of densities obtained for fresh concrete. Obviously, this behavior is due to the smaller density of the recycled aggregate compared to the natural aggregate.

Table 10

Characteristics of concrete with recycled aggregates

\begin{tabular}{|c|c|c|c|c|c|c|}
\hline Characteristics & $\begin{array}{c}\mathrm{R} 1 \\
0 \% \\
\text { recycled }\end{array}$ & $\begin{array}{c}\mathrm{R} 2 \\
20 \% \\
\text { recycled }\end{array}$ & $\begin{array}{c}\mathrm{R} 3 \\
40 \% \\
\text { recycled }\end{array}$ & $\begin{array}{c}\mathrm{R} 4 \\
60 \% \\
\text { recycled }\end{array}$ & $\begin{array}{c}\mathrm{R} 5 \\
80 \% \\
\text { recycled }\end{array}$ & $\begin{array}{c}\text { R6 } \\
100 \% \\
\text { recycled }\end{array}$ \\
\hline $\begin{array}{c}\text { Apparent density } \\
\text { hardened concrete, } \mathrm{kg} / \mathrm{m}^{3}\end{array}$ & 2358 & 2340 & 2336 & 2301 & 2290 & 2241 \\
\hline $\begin{array}{c}\text { Compressive strength, } \\
\mathrm{MPa} \\
\end{array}$ & 56,2 & 58,2 & 59,1 & 55,8 & 51,8 & 56,7 \\
\hline
\end{tabular}

The compressive strength of concrete has a surprising variation which was expected to decline by increasing the percentage of the recycled aggregate. This was not confirmed by the destructive tests carried out, much more so, in some compositions seeing a slight increase in strength to blank concrete with natural aggregate, fig. 4.

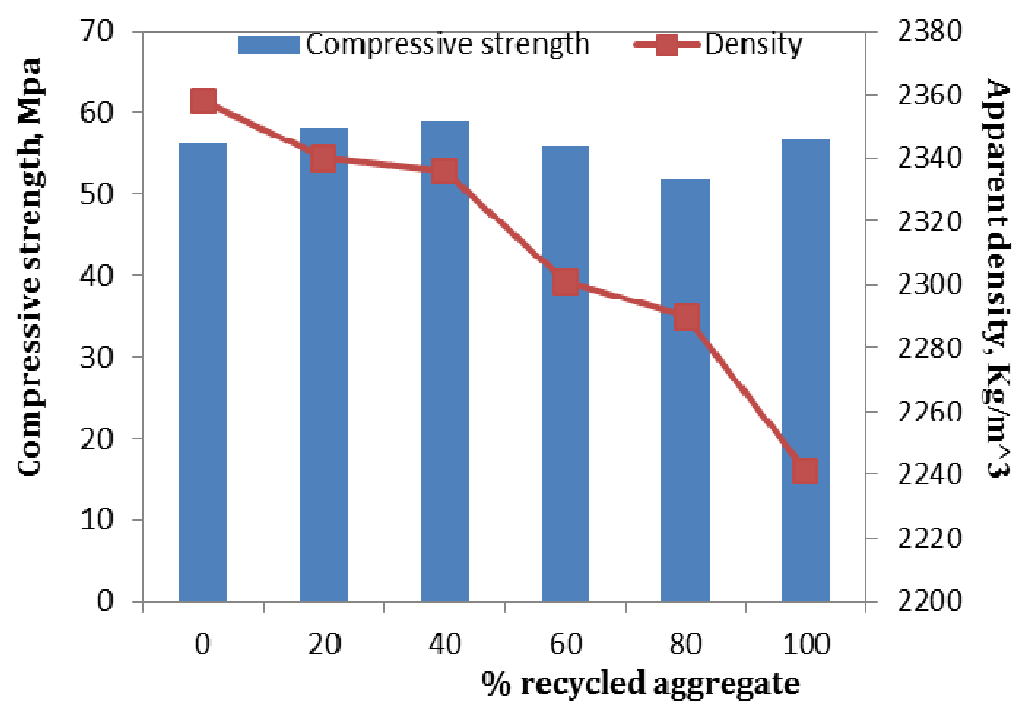

Fig.4 - The variation of apparent density and compressive strength of concrete, depending on the proportion of recycled aggregate content.

The explanations for such behavior arise from the following:

- concrete from which the recycled aggregate comes has not been used, its quality is very good, not containing impurities as it usually happens to the demolition aggregat;

- recycled aggregate was obtained by crushing, it has "fresh" surfaces, roughness, which provides a better adhesion to the cement paste compared to the river aggregate;

- un-hydrated cement granules of recycled aggregate allow the formation of additional amounts of hydrocomponents with binding properties, during setting and curing of the new concrete, which leads to a strengthening of the structure.

Note: Use of recycled aggregates in concrete is made on the basis of National/European specific prescriptions (SR EN 206: 2014), with limits for type A or B recycled aggregates. Aggregates obtained by crushing of hardened concretes unused in structural elements are considered reclaimed crushed aggregates, [29]. 


\section{Conclusions}

The paper presents a series of characteristics of recycled concrete aggregates of predefined class, mostly in comparison with characteristics of natural aggregates. It was highlighted the influence of the type of crusher used to obtain recycled aggregates on granulometry and granule shape and the influence of the attached mortar on the density, water absorption, behavior to the Los Angeles test etc. The proportion of attached mortar was determined and correlated with provenance concrete class of the recycled aggregates and their granulometric sort.

The aim to characterize the recycled aggregates is their valorification in new concretes used in construction. In this regard a series of concretes have been made in which the recycled aggregate content varied from 0 to $100 \%$. The new concretes were characterized from the point of view of change in the density and compressive strength with variation of the proportion of recycled aggregates. It has been shown that an increase in recycled aggregate content does not necessarily mean a reduction in compressive strength, the quality of the aggregate having a decisive role. The results were confirmed by data from the literature.

Another study will continue to show the influence of recycled aggregate content on other characteristics of the new concretes while in fresh or cured state.

\section{Acknowledgement}

This study was performed under a grant from the National Authority for Scientific Research, CNDI UEFISCDI, project number 145 / 02.07.2012.

\section{Bibliography}

[1]. Bressi, G., Volpe, G., Pavesi, E. (2011). The production of recycled aggregates from inert waste, ANPAR-Associazione Nazionale Produttori Aggregati Riciclati, Tecnitalia Consultants Milano. Italy: Press Centre of Emilia Romagna-Region

[2]. Garbarino, E., Cardu, M. (2008). Tecnologie di riciclaggio: impianti di trattamento ed applicazioni sperimentali d'impiego, INERTCH 2007, supplemento a RECYCLING, 62(8), 146-174.

[3]. Union Européenne des Producteurs de Granulats. (2010). Sustainable Development in the European Aggregates Industry - Annual Review, Brussels: Belgium UEPG aisbl.

[4]. Eurostat. (2008). Database

[5]. Leopold, D., Goga, M., Meissner, R. (2011). Ghid privind deşeurile din construcţii şi demolări, Sibiu, Romania: Casa de Presă şi Editură Tribuna, ISBN 978-973-7749-44-4.

[6]. Hendricks, C.F., Janssen, G.M.T. (2001). Reuse of construction and demolition waste in the Netherlands for road construction, Heron Journal, 4(2), 109-117.

[7]. Marinkovic, S., Ignjatovic, I., Radonjanin, V., Malesev, M. (2010). Recycled aggregate concrete for structural use - an overview of technologies, properties and applications, Aces workshop - Innovative materials and techniques in concrete construction, 10-12 October 2011 (pp.1-29). Corfu, Greece: http://www.academia.edu

[8]. Hirokazu, S., Hisashi, T., Ryuji, M., Yoshikuni, Y. (2005). An advanced concrete recycling technology and its applicability assessment through input -output analysis, Journal of Advanced Concrete Technology, 3(1), 53-67.

[9]. Hansen, T.C. (1986). Recycled aggregates and recycled aggregate concrete second state-of-art report developments 1945-1985, Lyngby, Denmark: RILEM Bordas-Gauthier-Villars

[10]. Zhang, W., Munn, C., Ingham, J.M. (2009). Recycled Concrete Aggregate and its Application in New Zealand, Ready mixed Production (Technical Papers TR 42), New Zealand Concrete Industries Conference.

[11]. Tabsh, S.W., Abdelfatah, A.S. (2009). Influence of recycled concrete aggregates on strength properties of concrete, Construction and Building Materials, 23(2), 1163-1167.

[12]. Öztürk, A.U., Erdem, T.R., Kozanoglu, C. (2012). Investigation of crushing type of concrete aggregates on mechanical properties of concrete, International Journal of Materials Engineering, 2(2), 6-9, DOI: 10.5923/j.ijme.20120202.02.

[13]. Deju, R., Robu, I., Dragusin, M., Mazilu, C., Tuca, C. (2015). Selection tests for recycled radioactive sand obtaining method, Romanian Reports in Physics, 67(2), 673-692.

[14]. Robu, I. (2009). Aspecte privind utilizarea de agregate reciclate şi subproduse industriale în beton, Simpozionul National "Noi reglementari pentru beton (Produse-Proiectare-Executie)", Octombrie 2009 (pp.191-195). Bucuresti, Romania: Ed.Conspress. 
[15]. Limbachiya, M.C., Marrocchino, E., Koulouris, A. (2007). Chemical-mineralogical characterisation of coarse recycled concrete aggregate, Waste Management, 27(2), 201-208.

[16]. Forster, S.W. (1986). Recycled Concrete as Aggregate, Michigan: American Concrete Institute.

[17]. Oikonomou, D.N. (2005). Recycled concrete aggregates, Cement \& Concrete Composites, 27, 315-318.

[18]. Evangelista, L., Brito, J. (2010). Durability performance of concrete made with recycled concrete aggregates, Cement \& Concrete Composites, 32, 9-14.

[19]. Malesev, M., Radonjanin, V., Marinković S. (2010). Recycled Concrete as Aggregate for Structural Concrete Production, Sustainability, 2, 1204-1225.

[20]. Grubl, P., Ruhl, M., Use of Recycled Concrete Aggregate, German Committee for Reinforced Concrete (DafStb)-(in ref. [21]).

[21]. Oikonomou, N.D. (2005). Recycled concrete aggregates, Cement and Concrete Composites, 27(2), 315-318.

[22]. Yaprak, H., Aruntas, H.Y., Demir, I., Simsek, O, Durmus, G. (2011). Effects of fine recycled concrete aggregates on the concrete properties, International Journal of the Physical Science, 6(10), 2455-2461.

[23]. Tabsh, S.W., Abdelfatah, A.S. (2009). Influence of recycled concrete aggregates on strength properties of concrete, Construction and Building Materials, 23(2), 1163-1167.

[24]. Safiuddin, M., Johnson, U., Abdus, M., Zamin, M., Fadhli, F., Binti, H. (2011). Properties of high-workability concrete with recycled concrete aggregate, Materials Research, 14, 248-255.

[25]. Shehata, M.H., Christidis, C., Mikhaiel, W., Rogers, C., Lachemi, M. (2000). Reactivity of reclaimed concrete aggregate produced from concrete affected by alkali-silica reaction, Cement and Concrete Research, 40(4), 575-582,

[26]. Neville, A.M. (2003). Proprietatile betonului, editia a IV-a, Bucuresti: Editura Tehnica.

[27]. Robu, I., Mazilu, C. (2015). Materiale de Constructie, Vol.I, București: Ed.Conspress, ISBN 978-973-100371-9; ISBN 978-973-100-372-6

[28]. Sanchez de Juan, N., Gutierrez, P.A. (2009). Study on the influence of attached mortar content on the properties of recycled concrete aggregate, Construction and Building Materials, 23(2), 872-877.

[29]. Organismul Naţional de Standardizare din România. (2014). Romanian Standard: Beton. Specificaţie, performanţă, producţie şi conformitate. SR EN 206:2014. Bucuresti. 